\title{
The Influence of Incentive towards their Motivation and Discipline (A Case Study at Rectorate of Andalas University, West Sumatera, Indonesia)
}

\author{
Frengki $^{1}$

\section{Aida Vitayala Hubeis ${ }^{2}$} \\ M. Joko Affandi ${ }^{3}$
}

${ }^{1,3}$ School of Business, Bogor Agricultural University, Indonesia

Email:frank_unand@yahoo.com Tel: +6285274510001

${ }^{2}$ Department of Communications Science and Community Development, Faculty of Human Ecology, Bogor Agricultural University, Indonesia Email:aidavitavala@yahoo.con

Email:joko@bkn.go.id

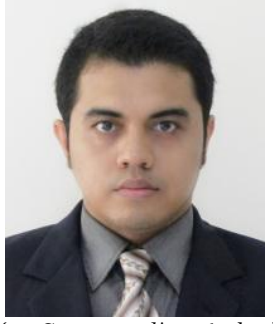

Corresponding Author

\begin{abstract}
There are several ways that can be done to improve employee performance, among others, by motivating employees and improving work discipline. Increased motivation and discipline can be pursued by the provision of incentive. This study aims to analyze the influence of incentive on Andalas University's employee motivation and discipline and analyze their perceptions on that allowance. This research was conducted by survey using questionnaire toward 78 educational staffs with civil servant status at rectorate of Andalas University. Data were analyzed quantitatively using descriptive analysis and Structural Equation Modeling (SEM). The results showed that the educational staff perceives that the incentive is feasible, allowances are able to increase productivity and improve welfare. However, they still feel that the application of incentive is not fair yet because it is not based on the actual workload. Based on statistical test, it was found that the incentive had a statistically significant and positive influence on work motivation and employee discipline.
\end{abstract}

Keywords: Discipline, Incentive, Motivation, Perceptions, Structural equation modeling.

Citation | Frengki; Aida Vitayala Hubeis; M. Joko Affandi (2017). The Influence of Incentive towards Their Motivation and Discipline The Infly Indonesia). Journal of Education and e-Learning Research, 4(4): 122128

History:

Received: 13 October 2017

Revised: 31 October 2017

Accepted: 3 November 2017

Published: 7 November 2017

Licensed: This work is licensed under a Creative Commons

Attribution 3.0 License (cc)

Publisher:Asian Online Journal Publishing Group
Contribution/Acknowledgement: All authors contributed to the conception and design of the study.

Funding: This study received no specific financial support

Competing Interests: The authors declare that they have no conflict of interests.

Transparency: The authors confirm that the manuscript is an honest, accurate, and transparent account of the study was reported; that no vital features of the study have been omitted; and that any discrepancies from the study as planned have been explained.

Ethical: This study follows all ethical practices during writing

\section{Contents}

1. Introduction

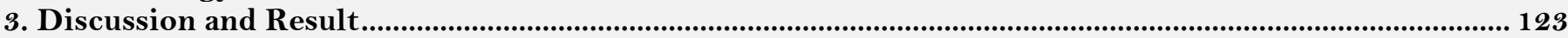

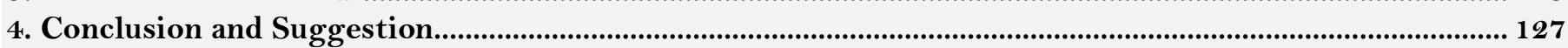

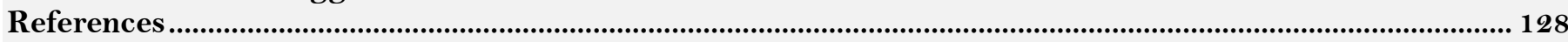

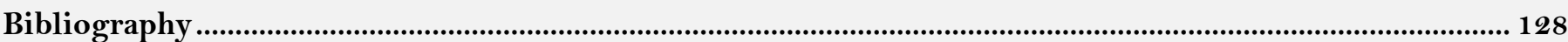




\section{Introduction}

A higher education has a big role in the Indonesia's growth and development, in order to produce quality and higher competent graduates. To get the goal, the higher education must have a good governance. The governance is a system management that ensures an accurate accountability and runs the organization system transparency. The concept about the management in the higher education's administration that adopted in Indonesia is good university governance. The implementation of the concept in the higher education is expected to meet requirement in supporting to handle all tasks and improve the higher education institution's capability. Ali (2011) one of them is by improving the educational staffs' performance. The individual's performance will be increase if the staffs have a high motivation and discipline. It is based on the research by Amanah (2011) which stated that the motivation and discipline give a significant effect to the staffs' performance.

To motivate the employee in working can be done by giving a fair and reasonable incentive. Schuler and Jackson (1999) said that the incentive can be used to motivate the employee in improving the productivity or to get the high performance. The theory is supported by the result of Al-Belushi and Khan (2017) stated that incentive has a direct effect to work motivation. An interesting financial incentive will improve almost all employees' work motivation. On the other hand, the incentive can improve to the employee's disciplinary in working too (Hasibuan, 2013). A goal in giving the incentive is to increase the discipline. It means that by giving a lot of incentive or compensation, the staff's discipline will be getting better and their loyality to the applicable rules and regulations will be higher. The above theory is supported by the Marwanto and Nugroho (2014) which wrote that the incentive's variable gives positive and significant effect to the working motivation and disciplinary.

Giving the financial incentive in performance allowance model to the civil servants of educational staffs in Andalas University (UNAND) is expected to improve their welfare, the performance's motivation and discipline. The incentive itself is based on the presidential regulation (Perpres) No. 32 of 2016 about the performance's incentive for civil servant within the ministry of research, technology and higher education and clarified by the minister of research, technology and higher education (Permen) No. 31 of 2016 about the giving of the employee's performance allowance within the ministry of research, technology and higher education.

The allowance that is accepted by the educational staffs increases the discipline. Unfortunately, there are some staffs still undiscipline. The discipline is as an indicator of performance because the level of staffs' presence in a company can be determined of the staffs' performance (Mathis and Jackson, 2006).

Factually, the educational staffs of UNAND is still undiscipline that can be depicted from the lateness in the working hours, so it gives a bad effect to the performance. The level of lateness of the educational staffs in UNAND is still high. In 2015 the average of lateness is about 24.47 percent and in 2016 is decreased to 22.80 percent. This phenomenon is higher in the beginning semester and it was decreased in the second semester be 22.80 percent in 2015 and 2016. This high lateness level will be influenced to the working performance. Giving the incentive is expected to be able to increase the civil servants' welfare and to stimulate their motivation in improving their performance.

\section{Methodology}

This research is descriptive with quantitative method through survey approach which used to get primary data about perception of educational staff to performance allowance and influence of performance allowance to motivation and discipline. Primary data collection is done by survey method by using questionnaire instrument. Secondary data used are obtained from various sources such as books, journals, articles, legislation and other relevant sources.

The questionnaire of this research used a scale of semantic differential. Morrisan (2014) semantic differential technique is used to know three general factors that include activity, potential and evaluation used to measure a person's attitude. To used this technique, we should put a name or concept above scale series bipolar attitude which consist of seven, six or five points and can be function as a anchor. Scheme of measurement by the scale of semantic differential such as:

$\begin{array}{lllllll}\text { Often } & 5 & 4 & 3 & 2 & 1 & \text { Never } \\ \text { Fast } & 5 & 4 & 3 & 2 & 1 & \text { Slow } \\ \text { Smart } & 5 & 4 & 3 & 2 & 1 & \text { Stupid }\end{array}$

In this research, the population is educational staff with a civil servant position in the rectorate of UNAND that consists of 340 person. The determine of sample size was done by using Slovin formula (Umar, 2005) with error level of $10 \%$,so based on Slovin formula is the number of samples to be 78 samples. The sample of taken by using probability sampling technique (technique that gives the same opportunity for every member of population to be a selected as a sampling). The method of chosen is disproportionate random sampling because for the rounding of 17 units later in percentage according to the proportion of the unit. In the selection of respondent by using random by doing with Microsoft excel the names and sequence numbers that will be used as research samples.

Processing and data analysis in this research include (1) descriptive using analysis descriptive of frequency and mode to perception analysis educational staff toward performance allowance. (2) Analysis structural equation modeling (SEM) with approach partial least square that used to analysis of influence performance allowance toward motivation and discipline of educational staff in working.

\section{Discussion and Result}

The performance allowance that is received by the civil servants of educational staffs in Andalas University's rectorate now should be based on the government's rule, have to fill the some criteria; fair, worthy, prodding the productivity and increasing the welfare. The result of the research can be seen on the Table 1, the high appearance number is 4 . It means that the performance allowance which is accepted by the civil servants' educational staffs in UNAND rectorate is worthy and able to fill the necessities of life. Absolutely, this allowance is expected to improve and prod the educational staffs' productivity in working, then it can increase and warrant the civil servants' educational staffs' welfare in UNAND rectorate. Conversely, the perception of the performance allowance that is according to questionnaire for the respondents by using the modus descriptive analysis is indicated unfair because 
the incentive is not suitable with the workload. The problem is occurred since the decision of grade to get a current position for the civil servants' educational staffs is unproperly between the task responsibility and the performance. It is why the analysis of task responsibility and job position evaluation is more important, so the fixing to the grading position system toward the educational staffs with their workload appropriately. It is hoped that the educational staffs think the giving performance allowance is fair. The perception of the civil servants' educational staffs of Andalas University's rectorate toward the performance allowance is displayed in several dimensions like in the Table 1 below:

\begin{tabular}{l|l}
\multicolumn{2}{l}{ Table-1. The perception of respondent to the performance allowance variable } \\
\hline Dimension & Modus \\
\hline Fair & 2 \\
\hline Worthy & 4 \\
\hline Productivity & 4 \\
\hline Welfare & 4 \\
\hline Source: data processing spss analysis
\end{tabular}

\subsection{Structural Equation Modeling Analysis \\ 3.1.1. Outer Model}

According to Jogiyanto (2011) to mark the validity and reliability model, the outer model can be used. The validity construction test consists of convergent validity and discriminant validity. The validity convergent test by using the reflection indicators is marked based on the loading factor. The discrimination validity examination can be checked in the cross loading mark in each indicator. The value in the cross loading among the constructs' indicators has to get higher mark more than others. The term model of a good validity is when the each latent variable with the reflection indicator has AVE more than 0.5. The AVE's square must be higher than the correlation's mark among variable. The reliability test is done to measure the consistence of the tool measurement internal by checking to the composite reliability's mark.

\subsubsection{Convergent Validity's Assessment}

Based on the result of convergent validity's assessment toward the research variable, the indicator has been met requirements of convergent validity's assessment, where the loading factor's marks should be more than 0.5, like the Table 2 below:

Table-2. Loading factor's marks of the convergent validity's assessment

\begin{tabular}{|c|c|c|}
\hline Code & Indicators & Loading factor's marks \\
\hline$\overline{\mathrm{A} 01}$ & Fair & 0.942 \\
\hline $\mathrm{AO2}$ & Workload & 0.941 \\
\hline$\overline{\mathrm{A} 03}$ & Position Responsibility & 0.908 \\
\hline Lo 1 & Worthy & 0.890 \\
\hline $\mathrm{LO} 2$ & Necessities of life & 0.895 \\
\hline$\overline{\mathrm{PO} 1}$ & Improving the work productivity & 0.973 \\
\hline $\mathrm{PO} 2$ & Prodding the work productivity & 0.969 \\
\hline So 1 & Improving the welfare & 0.948 \\
\hline So2 & Guaranteeing the welfare & 0.951 \\
\hline$\overline{\text { TJO } 1}$ & Doing the duty responsibly & 0.962 \\
\hline TJO2 & Finishing the duty responsibly & 0.937 \\
\hline$\overline{\mathrm{MRO} 1}$ & Work risks & 0.901 \\
\hline MRo2 & Work obstacle & 0.935 \\
\hline UBo1 & Leader and fellow workers's advices & 0.869 \\
\hline $\mathrm{UBO} 2$ & Self introspection for improvement & 0.934 \\
\hline KIO1 & Finishing the duty effectively & 0.852 \\
\hline KIO2 & Routine work & 0.708 \\
\hline WPTo1 & Delay work & 0.943 \\
\hline WPTO2 & Finishing the work of usual & 0.946 \\
\hline KMo1 & Success in working & 0.873 \\
\hline KMO3 & Improving the performance & 0.881 \\
\hline SOO 1 & Coming on time & 0.861 \\
\hline$\overline{\mathrm{SOO} 2}$ & Applying work hours & 0.816 \\
\hline SO03 & The end of the work hours Ideally. & 0.685 \\
\hline MPO1 & SKP's work achievement's standard & 0.673 \\
\hline$\overline{\mathrm{MPO} 2}$ & SOP's work successment supporting & 0.689 \\
\hline MP03 & Office tools in improving the work successment supporting & 0.728 \\
\hline $\mathrm{MPO4}$ & Obedient to the leader's command & 0.867 \\
\hline MP05 & Fulfill the leader's expectation in work comprehensiveness & 0.771 \\
\hline MSO 1 & Rules to require the employees to be discipline & 0.877 \\
\hline $\mathrm{MSO2}$ & The rule's influence toward the employees' knowledgment and competence. & 0.699 \\
\hline MSO3 & Using of work uniform & 0.797 \\
\hline MSO4 & Identity as employees & 0.784 \\
\hline MSO5 & Maintenance of office tools & 0.805 \\
\hline
\end{tabular}




\subsubsection{The Composite Reliability's Assessment}

The result of the composite reliability's assessment proves that the reliability's mark in each the second orders and also in the first orders of the performance allowance's variables that are formed by four dimensions; fair, worthy, productivity and welfare have been fulfill the composite reliability's criterias, where the criterias are to measure the internal consistency of measuring instruments that has a standard value is above 0.7. The motivation variables that are formed of six dimensions; responsibility, risk's consideration, feed back, creativity and innovative, time to finish the duty, and the willing to be the best, have also been fulfilled the composite reliability's criterias as a standard value above 0.7. For the discipline variables are formed of three dimensions; on time, work process, and obedient, are also fulfilled the composite reliability's criterias that has a standard value above 0.7. So, the variables, dimensions and indicators that are used in the research have been fulfill reliability's requirement as measuring instruments or able to measure consistenly and stability.

Table-3. The reliability's value in each the second order and first order of the performance allowance's, motivation and discipline variables

\begin{tabular}{l|l|c}
\hline \multicolumn{1}{c}{ Variables } & Dimensions & Composite Reliability \\
\hline Performance allowance & & 0.920338 \\
\hline & Fair & 0.950776 \\
\hline & Worthy & 0.886892 \\
\hline & Productivity & 0.970678 \\
\hline & Welfare & 0.948410 \\
\hline Motivation & & 0.905576 \\
\hline & Responsibility & 0,948178 \\
\hline & Risk's consideration & 0.914859 \\
\hline & Feed Back & 0.897229 \\
\hline & Creative and innovative & 0.759150 \\
\hline & The time in finishing a duty & 0.942655 \\
\hline & The willing to be the best & 0.869554 \\
\hline Discipline & & 0.899770 \\
\hline & On time & 0.832460 \\
\hline & Work process & 0.863322 \\
\hline
\end{tabular}

Source: data processing analysis of structural equation modeling (SEM)

\subsubsection{The Discriminant Validity's Measurement}

The result of discriminant validity's measurement shows that the AVE's mark in all variables, dimensions and indicators have been more that 0.5. It means that the latent variable in the research is good and fulfills the one of the discriminant's validities. Besides the using of AVE's mark to observe about the discriminant validity is also able to be observed from the mark of AVE's square root; should be higher than the correlation's mark of the other variables. Like in the Table 4, the fair variable has the mark of AVE's square root about 0.93 higher than other correlation's mark between the fair variables with others that is about 0.398, and also the mark of AVE's square root in the willing to be the best's variable is about 0.877 higher than the correlation's mark between the willing to be the best's variable with others is about 0.566. The same result is also achieved for other variables and dimensions where the AVE's square root is higher than the correlation's mark for the other variables. It means that all latent variables in the research have a good discriminant validity where the using of dimensions and indicators have been valid to be measured the other latent variables. For the AVE's mark and square root can be seen in the Table 4 below:

Table-4. The Mark of AVE's Squre Root

\begin{tabular}{l|l|l|l}
\hline & AVE & AVE's Square Root & The Maximum Correlation's Mark \\
\hline Fair & 0,865598 & 0.930375193 & 0,398720 \\
\hline Willing to be the best & 0,769217 & 0.87705017 & 0,566744 \\
\hline Obedient & 0,631100 & 0.794418026 & 0,714051 \\
\hline On time & 0,625644 & 0.790976612 & 0,403031 \\
\hline Creative and innovative & 0,613742 & 0.783416875 & 0,506672 \\
\hline Worthy & 0,796772 & 0.89262086 & 0,189462 \\
\hline Risk consideration & 0,843125 & 0.918218384 & 0,392931 \\
\hline Productivity & 0,943026 & 0.971095258 & 0,320796 \\
\hline Work process & 0,560261 & 0.748505845 & 0,698367 \\
\hline Responsibility & 0,901881 & 0.949674155 & 0,323040 \\
\hline Feed Back & 0,901477 & 0.949461426 & 0,294024 \\
\hline Time in finishing the duty & 0,813805 & 0.902111412 & 0,698367 \\
\hline
\end{tabular}

Source: data processing analysis of structural equation modeling (SEM)

The analysis' result is demonstrated that the mark of loading factor, composite reliability, and AVE in every construction is more than the settled model standard. The cross loading mark in every construction indicator is overall higher than the others (Table 2). Thus, the research of outer reflection model has been completed the standard both reliability and validity. 
Table-5. The result of assessment's criteria and mark standard in outer reflection model

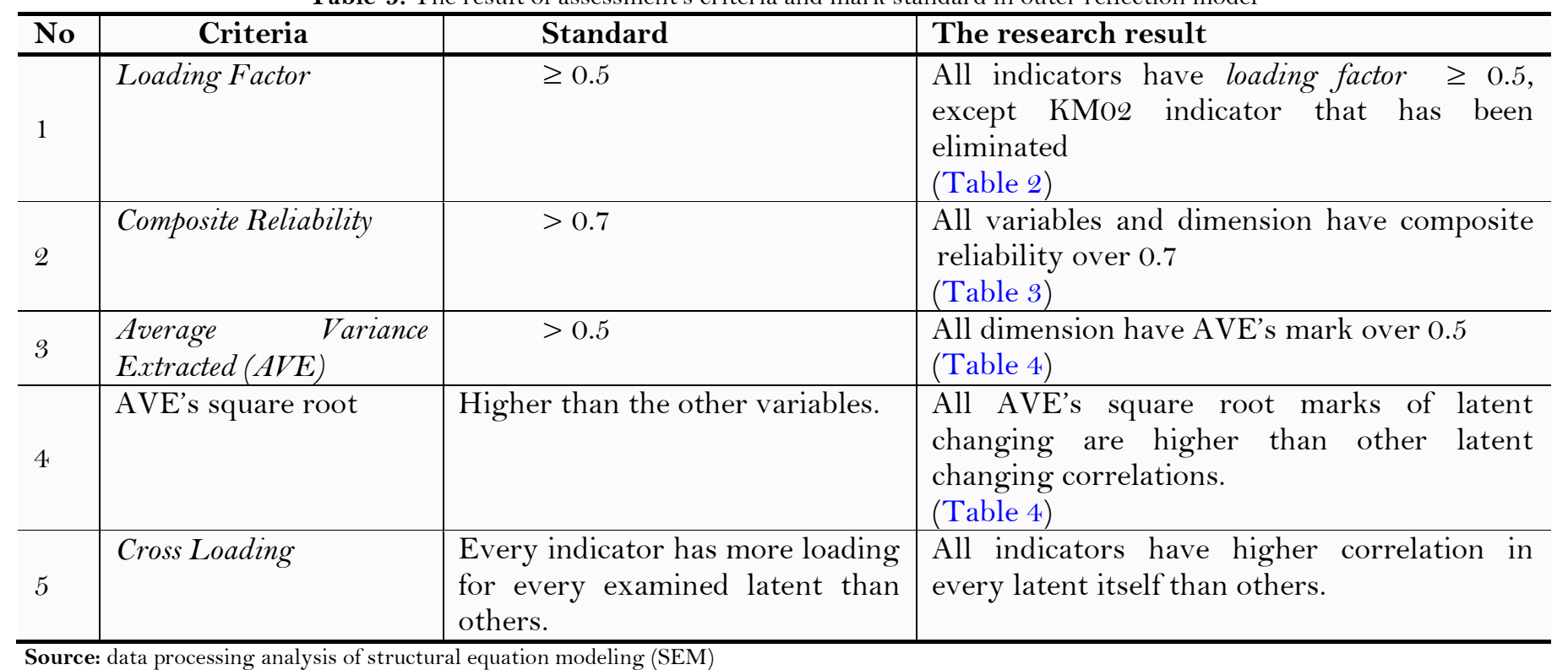

Source: data processing analysis of structural equation modeling (SEM)

\subsubsection{Inner Model}

Inner model is a structural model to predict the causality relationship among the latent changing. The model is evaluated by using $R$-Square for dependent construction, path coefficient value or path coefficient value, or path $t$ value to the real level in the hypothesis test. Inner model evaluation is to evaluate the construction influence among the latent and hypothesis tests the structural model is evaluated by using $R$-Square for endogen changing and t-count's comperation with the t-table (t-table in an interval of $95 \%$ trustworthiness is 1.974). Based on the data processing's results can be found that $\mathrm{R}^{2}$ value for the discipline variables is 0,1335 . It indicates that the discipline variable can be explained by the performance allowance is about 13 percent where is proved the fair between workload and the position responsibility, worthy in filling the necessity of life, improving the work productivity and prodding the work productivity, improving the welfare and able to gurantee the welfare, the amount left over can be explained by the other variables. While, for the motivation variable has a $\mathrm{R}^{2}$ mark about 0.1287 , it means that the motivation variable can be explained by the performance allowance variable is about 12,8 percent; fair, worthy, productivity and welfare, the amount left over can be explained by the other variables. This condition can be comprehended because there is only one eksogen variable from the both that will be influenced to.

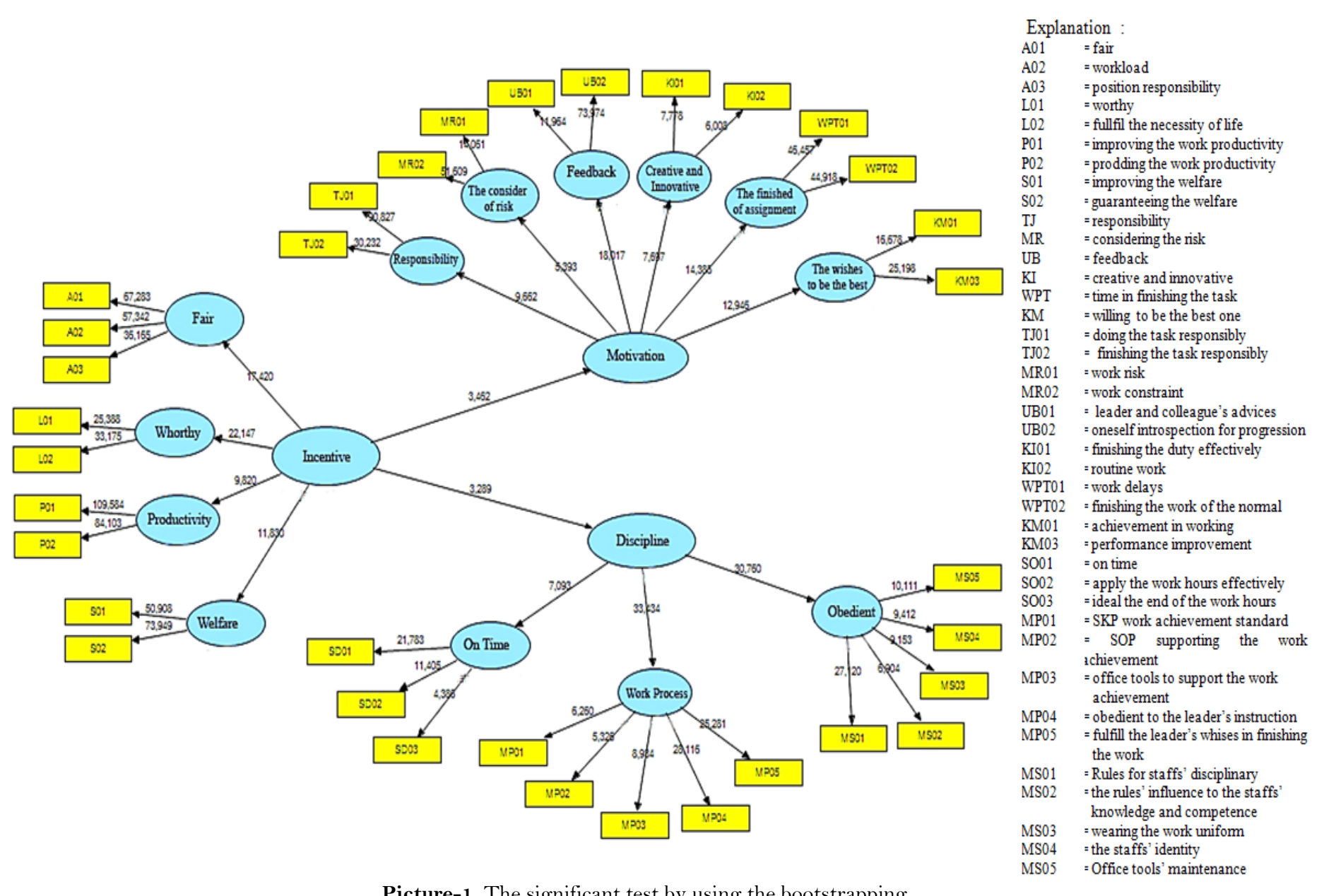

In the Picture 1 the significant test by using the bootstrapping, the independent variable (performance allowance) has ben tested to the dependent variable (motivation and discipline) can be result like in the Table 3 below: 
Table-6. Path coefficient (Mean, STDEV, T-Values)

\begin{tabular}{l|l|l|l|l|l}
\hline \multicolumn{2}{|c|}{$\begin{array}{l}\text { Original } \\
\text { Sample }(\mathbf{O})\end{array}$} & $\begin{array}{l}\text { Sample } \\
\text { Mean }(\mathbf{M})\end{array}$ & $\begin{array}{l}\text { Standard Deviation } \\
(\text { STDEV) }\end{array}$ & $\begin{array}{l}\text { T } \\
(\mid \mathbf{O} / \text { STERR }\end{array}$ \\
\hline Performance Allowance -> Discipline & 0,365464 & 0,367191 & 0,111129 & 3,288635 \\
\hline Performance allowance-> Motivation & 0,358792 & 0,355822 & 0,103636 & 3,462038 \\
\hline \multicolumn{2}{l}{ Source: data processing analysis of structural equation modeling (SEM) } & with the bootstrapping \\
\hline
\end{tabular}

Source: data processing analysis of structural equation modeling (SEM) with the bootstrapping

\subsection{The Result of Data Analysis Influence of Performance Allowance towards Motivation and Discipline.}

\subsubsection{The Influence of Performance Allowance towards Motivation}

The performance allowance has a significant direct effect on motivation. Based on the result of research the performance allowance have directly positive influence significant towards motivation the amount of 0.355822 significantly to the motivation of 0.355822 indicating the direction of the relationship of performance allowances with motivation is positive. After that based on the result of T-values amount of 3.46 the bigger from T-table 1,974 at $95 \%$ confidence intervals and at $5 \%$ alpha level, and $\mathrm{df} 77$ so that it can be concluded that the second hypothesis is acceptable or it can be said that the performance allowance has a significant direct effect on motivation.

The indicators that reflect motivation factor in this research are responsibility, doing and finished assignment with feel of responsibilities. Taking into account the risks that are willing to accept job risks and overcoming obstacles in the job. Also in accept of feedback, want to accept of suggestion from the leadership. Also in receiving feedback, willing to accept suggestions from the leadership and also colleagues in facilitating the task in the work so as to be able to motivated. By motivated of educational staff can be creative and innovative so that can be find news ways in finished assignment so that more effective and efficiently. In fact, by the times motivation in finishing assignment will be faster, want to be better for achievement so that as to improve of performance.

The results of this study support research conducted by Suryati (2010); Rochmat et al. (2013) states that incentives or compensation received by employees have a significant effect on motivation in work so that employees can improve its performance. While research conducted Ulfa et al. (2013); Sudarsono (2008); Afrida et al. (2014); Rufaidah et al. (2017); Hidayanto et al. (2014) which states that financial compensation and non-financial compensation are very influential on employee motivation in working either partially or simultaneously, so that the compensation is one of the things that should be paid attention to the compensation should be fair. Similarly the research that is done by Sverdlin (1988) that stated the incentive is the most effective to motivate the employees or staffs, where the financial reward is always be a main priority for them.

\subsubsection{The Influence of Performance Allowance toward Discipline}

The performance allowance has a direct effect to discipline significantly. Based on the research's result, the performance allowance has a positive direct effect significantly toward the discipline about 0,367191 that showed the relationship between the performance allowance and discipline is positive. Then based on T-values 3.28 is higher than T-table 1.974 in trust about $95 \%$ and in alpha's level $5 \%$ and $\mathrm{dg} 77$, thus it can be concluded that the performance allowance has a direct effect significantly toward the discipline.

In this research, the indicator that is reflected of the disciplinary is on time. It means if someone come on time, he will be use his work hours maximally until the end of the work hours. Then, in the work process, in this case is reflected the role of employee's job in work performance. There is a supporting the work achievement (SOP) that supported in working successfully, using the office tools to support the work process, the obedient to the leader's command. Thus, the obedient to the leader's command and social norm, where there are rules to guide the employee be discipline and also to improve the employee's knowledgement and competence. It is also about the disciplinary in wearing the employee's uniform and attribute and in maintaining the office tools.

The research's result is as same as the researches had been done by Beta (2015); Prabowo and Djastuti (2014); Putri (2015) and Yusuf (2016) stated that the incentive or compensation gives a big effect significantly to the work discipline. It is also stated in the research by Siahaan (2013) giving reward to the employee also have a significant effect toward the employee's discipline in working.

\section{Conclusion and Suggestion}

\subsection{Conclusion}

Based on the data analysis' result that has been explained in the discussion, it can be concluded that:

1. The research result showed that the civil servant educational staffs argue that the performance allowance is unfair because it is not suitable with the workload. The civil servant also state that the performance allowance has been worthy and able to fill the necessity of life, prod and improve the work productivity. In addition, the civil servant educational staffs have a perception that the performance allowance is able to improve and gurantee their welfare.

2. The performance allowance has direct effect to the motivation significantly. It can be seen from the T-values is higher than T-table that indicates the positive relationship between the performance allowance and the motivation, because the allowance can support the educational staffs do and finish the duty responsibly, more creative and innovative in doing the job and desire in achievement to be the best one.

3. The performance allowance has direct effect significantly to the discipline and show the positive relationship between the allowance and the discipline.

\subsection{Suggestion}

1. It needs to analyze about the workload and position's evaluation in order to fix the grading position system to the educational staff toward the workload, so the educational staffs feel a fair performance allowance.

2. For the Andalas University that will be the university states incorporate (PTN BH), is needed to pay attention in arranging the remunaration's value given. It is because the incentive can be give a positive and significant effect to the motivation and discipline. 
3. The next research is adviced to use the other variables to study the influence of performance allowance to the motivation and the work discipline and also the implication to the civil servant education staffs in Andalas University.

\section{References}

Afrida, Z., B.S. Sunuharyo and E.S. Astuti, 2014. Influence of financial and non-financial compensation on work motivation and employee performance (Study on Employee of Production Department of PT Ekamas Fortuna Malang). Journal of Business Administration, $12(1): 1-9$.

Al-Belushi, F.Y. and F.R. Khan, 2017. Impact of monetary incentives on employee's motivation: Shinas college of technology, oman - a case study. International Journal of Management, Innovation \& Entrepreneurial Research, 3(1): 1-1 1. View at Google Scholar $\mid$ View at Publisher

Ali, H.M., 2011. Membangun good governance pada perguruan tinggi di Indonesia. [diunduh 2017 Agustus 01 ]. Tersedia pada.

Amanah, D., 2011. The influence of motivation and discipline on the performance of employees at PT. Istana Deli Kencana I. Journal of Finance and Business, 3(1): 11-22. View at Google Scholar

Beta, A.A., 2015. The effect of job characteristics and compensation on work discipline and its impact on employee performance on revenue and asset management of Rokan Hulu district. Scientific Journal of Cano Ekonomos, 4(1): 1- 10.

Hasibuan, M.S.P., 2013. Human resource management. Jakarta: Bumi Aksara.

Hidayanto, A., D. Hamid and M. Hakam, 2014. The influence of financial and non-financial compensation on employee motivation and performance (Study on Employees of PT AXA Financial Indonesia Branch of Malang). Journal of Business Administration, 10(1): $1-9$.

Jogiyanto, H.M., 2011. Concepts and applications structural equation modeling: Varian based in business research. Yogyakarta (ID): UPP STIM YKPN

Marwanto, T. and R. Nugroho, 2014. The influence of compensation and work environment on the motivation and discipline of soldier work in KRI X Armada of Eastern Indonesia. Journal of Economics and Management, 1(1): 74- 82.

Mathis, R. and J. Jackson, 2006. Human resource management. 10th Edn., Jakarta (ID): Salemba Empat.

Morrisan, 2014. Survey research methods. Jakarta (ID): Prenadamedia Group.

Prabowo, D. and I. Djastuti, 2014. Effect of compensation and supervision of the leadership on the discipline of the employee's work in the revenue, financial management and asset of Batang district. Diponegoro Journal of Management, 3(3): $1-12$.

Putri, N., 2015. The influence of supervision and financial compensation to work discipline on employees at PT. Sentra Karya Cahaya Raya in Pekanbaru. Journal of Jon Fekon, 2(2): 1- 15.

Rochmat, K., D. Hamid and M. Hakam, 2013. Influence of incentives on motivation and performance (Studies on Non-permanent Employees / Agents AJB Bumiputera 1912 Batu Branch Office). Journal of Business Administration, 1(1): 19-27.

Rufaidah, R., H. Hutami and Y. Mayowan, 2017. The influence of financial and non-financial compensation on work motivation and employee performance (Study on Permanent Employees of PG Kebon Agung Malang). Journal of Business Administration, 42(1): $181-188$.

Schuler, R. and S. Jackson, 1999. Human resource management: Facing the 21 st century. Translation Abdul Rosyid, S.S. dan Peter Remy Yosy Pasla. Jakarta: Erlangga, 2 .

Siahaan, R., 2013. Effect of reward and punishment on employee work discipline at PT. plantation archipelago III Rambutan. Bussiness Progress Scientific Journal, 1(1): 17- 26.

Sudarsono, H., 2008. Analysis of the effects of compensation on motivation and performance (Case Study of Economics Lecturer at Private Universities). Journal of Educational Research, 18(1): 144- 153.

Suryati, 2010. The effect of compensation on employee work motivation. Journal of Mimbar Bumi Bengawan, 3(7): 1- 13.

Sverdlin, O., 1988. Affect of incentives on motivation of hotel workers: A case study of the grand hotel Europe, st. Petersburg, Russia. [tesis]. ST. Peterburg (RUS): University of Wisconsin-Stout.

Ulfa, M., K. Rahardjo and I. Ruhana, 2013. Effect of compensation on work motivation and employee performance (Study on auto employees 2000 Malang Sutoyo). Journal of Business Administration, 3(1): 1- 11.

Umar, H., 2005. Research on human resources in organizations. Jakarta (ID): PT. Gramedia Pustaka Utama.

Yusuf, M., 2016. The influence of the principal's leadership, achievement motivation, and compensation for the discipline of high school teachers of Negeri 1 Sinjai Selatan. Journal of Competitiveness ADPEN, 10(2): 101- 113.

\section{Bibliography}

Peraturan, M.R., 2016. Minister of research, technology and higher education No. 31 of 2016 about the giving of the employee's incentive within the ministry of research, technology and higher education. Jakarta (ID) : Kemenristekdikti.

Peraturan, P., 2016. Presidential regulation No. 32 of 2016 about the performance's incentive for civil servant within the ministry of research, technology and higher education. Jakarta (ID) : Sekretariat Negara. 